$a l^{7}$ did not show the results of their assay in patients with other rheumatic diseases. However, the fact that $2 / 5$ of their control sera were also positive indicates that their assay is not specific. Finally, since ANA are found in a very large proportion of pauciarticular onset JCA patients $(88 \%$ in our study), we do not think that the presence of anti-RA 33 antibodies in this particular subset of patients could add any useful information. In addition, anti-RA 33 antibody assay is clearly longer to perform and less widely available than ANA test.

In conclusion, we think that there is not enough evidence to support a wider use of APF and anti-RA 33 antibody assay in JCA.

Division de Rhumatologie Hôpital Cantonal Universitair CH-1211 Geneve 14 Switzerland

OLIVIER MEYER Clinique de Rhumatologi Hôpital Bichat Claude-Bernard F-75018 Paris

France

ANNE-MARIE PRIEUR Unité fonctionnelle de Rhumatologie pédiatrique Hôpital des 'Enfants-Malades' F-75015 Paris

France

1 Meyer O, Tauxe F, Fabregas D, Haim Th, Kahn M-F. Antiperinuclear factor (APF), antikeratin (AKA), and anti-RA 33 antibodies in rheumatoid arthritis (RA). Clin Rheum 1992; 11: 130. (Abst)

2 Von Essen R, Ylijoki H, Savolainen A, Haapasaari J, Ulla-Maija O. Antiperinuclear factor in juvenile chronic arthritis. Ann Rheum Dis 1992; 51: 1264.

3 Nesher G, Moore T L. Antiperinuclear factor in juvenile rheumatoid arthritis. Ann Rheum Dis 1992; 51: 1264 .

4 Vivino F B, Maul G G. Histologic and electron microscopic characterization of the antiperinuclear factor antigen. Arthritis Rheum 1990; 33: 960-9.

5 Youinou P, Le Goff P, Dumay A, Lelong A, Fauquert $P$, Jouquan J. The antiperinuclear factor. I. Clinical and serologic associations. Clin Exp Rheumatol 1990; 8: 259-64.

6 Meyer O, Tauxe F, Fabregas D, et al. Anti-RA 33 antinuclear autoantibodies in rheumatoid arthritis and mixed connective tissue disease: comparison with antikeratin and antipericomparison with antikeratin and antiperi11: $473-8$.

7 Wilson V K, Osborn T G, Hanna V E, Moore $T$ L. Presence of RA 33 in pauciarticularonset juvenile rheumatoid arthritis. Arthritis Rheum 1993; 36: S209. (Abst)

\section{Circulating $T$ cell subtypes in polymyalgia rheumatica and giant cell arteritis: variation in the percentage of CD8+ cells with prednisolone treatment}

We would like to respond to the paper by Pountain et al on circulating $T$ cell subsets in PMR and GCA in which they failed to find a decrease of $\mathrm{CD} 8+\mathrm{T}$ cells in contradistinction to our work. ${ }^{2}$

1 Our published studies have been done on patients before treatment with corticosteroids. This is also true for the studies by Elling et $a l,{ }^{3}$ Dasgupta $e t a l,{ }^{1}$ and Chelazzi and Broggini. ${ }^{4}$
2 Patients in our studies, whether single or multi-centre, had blood taken at the same time on each occasion.

3 In our multi-centre studies blood was collected into sequestrene and dispatched by post for analysis within 24 hours. We have checked this method and have found no difference in the absolute numbers or proportions of CD8+ $\mathrm{T}$ cells (paper in press). This supports already published work. $^{5}$

4 Although in our first study, ${ }^{1}$ we used 'lymphoprep' separation which is known to decrease both CD4+ and CD8+ T cells, in our subsequent work we have used a whole blood method which shows decreased CD8+ $\mathrm{T}$ cells in untreated patients with PMR (unpublished data).

Thus if steroid treatment, diurnal variation, storage conditions and leucocyte separation cannot account for the different results obtained by the Cambridge group and ourselves, what does? We believe it is the method of enumeration of $T$ cell subsets. The only difference that we can ascertain is that whereas they use the Simulset software to gate for lymphocytes, we do this manually. The final answer must surely come from the exchange of samples and direct comparison of the two techniques.

G S PANAYI Rheumatology Unit Division of Medicine Floor 4, Hunt's House Guy's Hospital London Bridge London SE1 9RT United Kingdom

1 Dasgupta B, Duke O, Timms A M, Pitzalis C, Panayi G S. Selective depletion and activation of CD8+ lymphocytes from peripheral blood of patients with polymyalgia rheumatica and giant cell arteritis. Ann Rheum Dis 1989; 48: giant cell

2 Arnold M H, Corrigall V M, Pitzalis C, Panayi G S. The sensitivity and specificity of reduced CD8 lymphocyte levels in the diagnosis of polymyalgia rheumatica/giant cell arteritis. Clin Exp Rheumatol (in press)

3 Elling $P$, Olsson A, Elling $H$. CD8+ T lymphocyte subset in giant cell arteritis and related disorders. $\mathcal{F}$ Rheumatol 1990; 17: 225-7.

4 Chelazzi G, Broggini M. Abnormalities of peripheral blood $\mathrm{T}$ lymphocyte subsets in polymyalgia rheumatica. Clin Exp Rheumatol 1984; 2: 333-6.

5 Ekong T, Hill A M, Gompels $M$, Brown A, Pinching A J. The effect of the temperature and duration of sample storage on the measurements of lymphocyte subpopulations from HIV-1 positive and control subjects. F Immunol Methods 1992; 151(1-2): 217-25.

AUTHORs' REPLY: We thank Professor Panayi for his comments. There are certainly puzzling differences between studies of CD8+ cells in PMR/GCA. Corticosteroid treatment does alter $\mathrm{T}$ cell subsets as we have shown in healthy volunteers, ${ }^{1}$ but if initial blood samples from PMR/GCA patients have been obtained before any corticosteroid treatment, the chief sources of variation are likely to be transport and storage of specimens, mismatch of control samples, and technical methods of $T$ cell enumeration. We cannot comment on the three unpublished studies referred to by Professor Panayi, so we confine ourselves here to discussing the published work.

1 Ekong et $a l^{2}$ did not find any fall in $\% \mathrm{CD} 8+$ cells after storage of cells at a range of temperatures when using the whole blood lysis technique. When using this technique Ashmore et $a l^{3}$ similarly did not find any fall in \%CD8, but when using the Ficoll Hypaque method they showed a marked reduction in both \%CD $4+$ and $\%$ CD $8+$ cells on blood stored for 24 hours at $4^{\circ} \mathrm{C}$. Unfortunately, storage at higher temperatures was not investigated, but it is clear from this work that the data on blood storage cannot be extrapolated from the whole blood lysis technique to the Ficoll Hypaque method. As most of the studies before ours had used the Ficoll Hypaque method (including the Guy's study ${ }^{4}$ ) the data from Ekong et al does nothing to reassure us that storage conditions are unimportant. When specimens are transported by post the conditions must be at best unpredictable.

2 In our paper we referred to the importance of matching controls for age (which has usually been done in the published work) and for the time of day of blood sampling. Professor Panayi's letter refers to the constant timing of patient samples in the Guy's multicentre study ${ }^{4}$ but does not specify if the control samples were matched for time of day. This, in addition to the storage differences between control and patient samples, could introduce variation. In following patients on corticosteroids, the $T$ cell data cannot be interpreted unless we know whether samples have been taken before or after the daily steroid dose, as the interval since the last dose affects the $T$ cell subsets. ${ }^{1}$

3 The whole blood lysis method has largely superseded the Ficoll Hypaque method for separation of mononuclear cells. Hence it is desirable that further studies in PMR/GCA be published using this method. The other possible source of variation referred to by Professor Panayi is the setting of the lymphocyte gate. Although we use the Simulset software for the subsequent analysis, the lymphocyte gate is set manually, which the Guy's group also do.

In summary, there are still several question marks hanging over the role of CD8+ cells in PMR/GCA, therefore at present we cannot recommend CD8 enumeration as helpful in assessing this disease.

$$
\begin{array}{r}
\text { GILLIAN POUNTAIN } \\
\text { MARY KEOGAN } \\
\text { DAVID BROWN } \\
\text { BRIAN HAZLEMAN } \\
\text { Rheumatology Research Unit } \\
\text { Box No 194, Unit E6 } \\
\text { Addenbrooke's Hospital } \\
\text { Hills Road } \\
\text { Cambridge CB2 } 2 Q Q
\end{array}
$$
United Kingdom

1 Pountain G D, Keogan M T, Hazleman B L, Brown D L. Effects of single dose compared with 3 days prednisolone treatment of healthy volunteers: contrasting effects on circulating volunteers: contrasting effects on circulating
lymphocyte subsets. $\mathcal{F}$ Clin Pathol 1993; lymphocyte

2 Ekong T, Hill A M, Gompels M, Brown A, Pinching A J. The effect of the temperature and duration of sample storage on the measurement of lymphocyte subpopulations from HIV-1-positive and control subjects. 7 Immunol Methods 1992; 151: 217-25.

3 Ashmore L M, Shopp G M, Edwards B S. Lymphocyte subset analysis by flow cytometry. Comparison of 3 different staining techniques and effects of blood storage. $\mathcal{J}$ techniques and effects of blood stora

4 Dasgupta B, Duke O, Timms A M, Pitzalis C, Panayi G S. Selective depletion and activation of CD8+ lymphocytes from peripheral blood of patients with polymyalgia rheumatica and of patients with polymyalgia rheumatica and giant cell 